\title{
THE SYMPATHETIC RESPONSE TO PROFOUND HYPOTHERMIA AND CIRCULATORY ARREST IN INFANTS
}

\author{
Margaret WoOd, D.G. Shand and A.J.J. Wood
}

\begin{abstract}
Anstract
It has been suggested that the increased incidence of ventricular arrhythmias recugnized below $30^{\circ} \mathrm{C}$ might be catecholamine mediated. Elevated catecholamine concentrations have been reported in experimentally induced hypothermia in animals.

Plasma concentrations of epinephrine and norepinephrine were measured during profound hypothe rmia and total circulatory arrest in infants under one year of age undergoing surgical correction of congenital cardiac defects. There was no significant change in either epinephrine or norepinephrine levels during surface cooling to $28^{\circ} \mathrm{C}$. Circulatory arrest and exsanguination at $18^{\circ} \mathrm{C}$ were not associated with a rise in catecholamine levels. However, there was a striking rise in the levels of both epinephrine and norepinephrine with the recommencement of bypass and rewarming. The mean plasma norepinephrine concentration rose from $466 \mathrm{pg} / \mathrm{ml}$ (SE \pm 81 ) at circulatory arrest to $4543 \mathrm{pg} / \mathrm{ml}$ (SE \pm 2058 ) on rewarming bypass $(\mathrm{p}<0.02)$. while the mean plasma epinephrine concentration rose from $218 \mathrm{pg} / \mathrm{ml}(\mathrm{SE} \pm 54$ ) at circulatory arrest to $3724 \mathrm{pg} / \mathrm{ml}$ (SE \pm 1064$)$ on rewarming bypass $(\mathrm{p}<0.02)$. The plasma catecholamine concentrations fell once cardiopulmonary bypass was discontinued, when the infant's temperature was $37^{\circ} \mathrm{C}$. It would, therefore, appear unlikely that the ventricular irritability recognized below $30^{\circ} \mathrm{C}$ is due to catecholamine excess. The accumulation of catecholamines and/or metabolic products in the infants during circulatory arrest with their subsequent release into the circulation during rewarming may account for the elevation of catecholamine levels during rewarming bypass.
\end{abstract}

THE TECHNique of profound hypothermia and circulatory arrest has been increasingly used by anaesthetists to facilitate the surgical correction of congenital cardiovascular defects in infants under one year of age. Profound hypothermia techniques have been developed to provide a period of circulatory arrest in which it is safe to perform an accurate and rapid primary repair of even complex defects within a totally relaxed and bloodless heart. A second advantage is that they limit the duration of cardiopulmonary bypass perfusion and prevent the deleterious effects of prolonged cardiopulmonary perfusion, especially in neonates and infants. At temperatures below $30^{\circ} \mathrm{C}$ ventricular arrhythmias may occur, including ventricular fibrillation and cardiac arrest, and this has limited the usefulness of hypothermia in other clinical situations. There are reports

Margaret Wood, M.B., Ch.B., F.F.A.R.C.S., Assistant Professor of Anesthesiology and Pharmacology; D.G. Shand, M.B., Ph.D., M.R.C.P., Professor of Medicine and Pharmacology*; A.J.J. Wood. M.B., Ch.B., M.R.C.P., Assistant Professor of Medicine and Pharmacology. Departments of Anesthesiology and Clinical Pharmacology, Vanderbilt University, Nashville, Tennessee, 37232

*Present Address: Division of Clinical Pharmacology, Duke University, Durham, North Carolina, 27707.

Supported by United States Public Health Service, Grant Nos. GM $1543 i$ and HL. 14192. that lowered body temperatures are a potent stimulus to endogenous catecholamine release ${ }^{1}$ and it has been suggested that the development of ventricular fibrillation during hypothermia might be catecholamine mediated. ${ }^{2.3}$ Because of the possibility of elevated catecholamine levels during induced hypothermia, propranolol has been used to manage arrhy thmias during cooling. ${ }^{4.5}$

Catecholamine release following acute exposure to cold has been reported in piglets 6 and rats $^{3.8}$ and during experimentally induced hypothermia in dogs. ${ }^{2.3}$ There is also evidence that urine catecholamine concentrations are elevated in fatal hypothermia viclims, indicating increased excretion due to acute accidental exposure to cold. ${ }^{9}$ We were therefore interested to investigate the effect of induced hypothermia on catecholamine release during general anaesthesia for infants undergoing surgical correction of congenital cardiac defects.

Plasma catecholamine concentrations have been determined during cardiopulmonary bypass in adults, with conflicting results. ${ }^{10.11}$ The large progressive increases in plasma catecholamines during cardiopulmonary bypass in adults reported in previous studies were not confirmed by Hine and his coworkers. During the period of circulatory arrest at $18^{\circ} \mathrm{C}$ while the repair of the defect is being carried out, a metabolic acidosis 
TABLE I

Details of The Infants Studied

\begin{tabular}{cccl}
\hline No. & Age (mths) & Weight (kg) & \multicolumn{1}{c}{ Diagnosis } \\
\hline 1 & 8 & 5.3 & Transposition of the great vessels \\
2 & 6 & 8.2 & Fallot's tetralogy \\
3 & 4.5 & 4.1 & AV canal defect \\
4 & 5 & 6.6 & Transposition of the great vessels \\
& & & and ventricular septal defect \\
5 & 7.5 & 6.8 & Transposition of the great vessels \\
6 & 10 & 7.5 & Transposition of the great vessels \\
7 & 8 & 6.4 & Ventricular septal defect \\
\hline
\end{tabular}

occurs, ${ }^{12}$ probably due to the production of lactic acid. ${ }^{13}$ A sympathetic response may occur due to the acidosis that results from the rewarming perfusion and the consequent washout of accumulated metabolic products from ischaemic tissues.

The relative insensitivity of flurometric techniques for assay of plasma catecholamines has made it difficult to detect small changes, but the advent of precise and sensitive radiometric methods for measuring plasma catecholamine levels dircetly ${ }^{14}$ has allowed us to investigate the adrenergic response to this procedure. Plasma catecholamine concentrations have recently been used extensively as a direct means of assessment of sympathetic neuronal activity. The present study was undertaken to investigate the sympathetic response to profound hypothermia. cardiopulmonary bypass, total circulatory arrest and rewarming in infants under one year of age undergoing surgical correction of cardiac defects.

\section{Patients and Methods}

Seven infants described in Table I were studied after informed consent had been obtained from their parents, the study having been previously approved by the institutional review committee. The patients were premedicated with morphine $0.1 \mathrm{mg} \cdot \mathrm{kg}^{-1}$ intramuscularly and atropine $0.02 \mathrm{mg} \cdot \mathrm{kg}^{-1}$ intramuscularly, $60-90$ minutes before the induction of general anaesthesia. After an inhalational induction of anaesthesia with halothane $0.5-1.0$ per cent, oxygen and nitrous oxide (50:50 per cent), tracheal intubation was carried out with the aid of succinylcholine $1.0 \mathrm{mg} \cdot \mathrm{kg}^{-1}$ intravenously. Following the intravenous administration of pancuronium $0.1 \mathrm{mg} \cdot \mathrm{kg}^{-1}$, ventilation was continued by hand with humidified nitrous oxide-oxygen (50:50 per cent) and halothane $0.2-0.5$ per cent using the
Jackson Rees modification of the Ayre's T-Piece. After the placement of arterial, central venous and intravenous lines, surface cooling was commenced using icebags which were applied to the infant's head, chest, abdomen and legs, but not to the precordium. The infants were surface cooled to an oesophageal temperature of $28^{\circ} \mathrm{C}$. When the oesophageal temperature reached $28^{\circ} \mathrm{C}$, the icebags were removed, the infants were prepared and draped and the sternal incision was made. After cannulation of the aorta and venous atrium. the infants were placed on cardiopulmonary bypass. Cardiopulmonary bypass and the extracorporeal circulation employed the Bentley. Temptrol infant oxygenator* with a priming volume of approximately $700 \mathrm{ml}$. A mixture of three per cent carbon dioxide and 97 per cent oxygen was bubbled through the oxygenator. The pump prime consisted of $230 \mathrm{ml}$ of fresh frozen plasma, plus plasmanate and citrate phosphate dextrose blood, in volumes calculated to achieve a haematocrit of 30 per cent in the infants during perfusion. The infants were perfused at flow rates between $1.6 \mathrm{l} / \mathrm{min} \cdot \mathrm{m}^{2}$ and $2.2 \mathrm{l} / \mathrm{min} \cdot \mathrm{m}^{2}$ body surface area. Cooling was continued to $18^{\circ} \mathrm{C}$ using the extracorporeal circulation. (Water from a coil immersed in a bucket of ice was circulated through the heat exchanger in the pump to achieve rapid core cooling of the infants.) When the infants' oesophageal temperature reached $18^{\circ} \mathrm{C}$, total circulatory arrest was established, perfusion was stopped and the infants' blood volume was drained to the reservoir chamber of the pump oxygenator. Following the repair of the cardiac defect, rewarming was begun using partial cardiopulmonary bypass to $37^{\circ} \mathrm{C}$. When the infants' temperature reached $37^{\circ} \mathrm{C}$, cardiopulmonary bypass was discontinued.

\footnotetext{
*Model Q130.
} 
Samples of arterial blood were taken at the following times during the procedure for the estimation of plasma epinephrine and norepinephrine concentrations: (1) immediately after induction of anaesthesia and before intubation, (2) during surface cooling above $32^{\circ} \mathrm{C}$, (3) during surface cooling $31^{\circ} \mathrm{C}-28^{\circ} \mathrm{C}$. (4) following the sternotomy, (5) during cooling bypass to $18^{\circ} \mathrm{C}$, (6) following circulatory arrest, (7) immediately after the infants" blood volume had been drained to the pump, (8) during rewarming bypass to $37^{\circ} \mathrm{C}$, (9) after bypass was discontinued, (10) and at the end of the operation.

The arterial blood samples were withdrawn from the peripheral arterial cannula, or from the reservoir chamber of the oxygenator during bypass. Blood samples for measurement of catecholamines were taken into tubes in ice containing reduced glutathione and then assayed for norepinephrine and epinephrine with a moditication of the technique of Passon and Peuler ${ }^{14}$ in which the methylated derivatives of catecholamines were produced in the presence of catechol-O-methyltransferase and tritiated Sadenosylmethionine and then separated by thin layer chromatography. At the same time as each blood sample was drawn for the measurement of norepinephrine and epinephrine concentrations in plasma, the patient's oesophageal temperature, heart rate and mean blood pressure were recorded. The patient's temperature was measured using an oesophageal thermister probe* and the electrocardiogram, heart rate and arterial blood pressure were recorded using a pressure transducer $\dagger$ and a four channel storage display oscilloscope $\ddagger$. Mean blood pressure was calculated as diastolic blood pressure plus one third of pulse pressure. Arterial blood gases were measured before surface cooling, during surface cooling, during cooling bypass, after ten minutes of rewarming bypass and when cardiopulmonary bypass was discontinued. Blood gas analysis was performed on a Corning 165 blood gas analyzer\$ with the water bath temperature set at $37^{\circ} \mathrm{C}$ and the $\mathrm{pH}$ and $\mathrm{PaCO}_{2}$ measurements were corrected for the difference between the $37^{\circ} \mathrm{C}$ electrode and the oesophageal temperature of the infant at the time the blood gas sample was drawn. ${ }^{15-17}$ The mean times elapsing between the following events and the taking of blood samples were:

*Model No. 43TD, Yellow Springs Co., Inc., Ohio. †Hewlett-Packard Model No. $1280 \mathrm{C}$.

$\ddagger$ Hewlett-Packard Model No. 78304A

$\$$ Corning Glass Works, Medfield, Massachusetts, 02052.
(1) preinduction to postinduction, 23.8 minutes ( $\mathrm{SEM} \pm 4.07$ );

(2) start of surface cooling to surface cooling to $32^{\circ} \mathrm{C}, 34.4$ minutes ( $S E M \pm 4.11$ );

(3) surface cooling $32^{\circ} \mathrm{C}$ to surface cooling $28^{\circ} \mathrm{C} .22 .8$ minutes ( $\mathrm{SEM} \pm 3.98$ );

(4) sternotomy incision to institution of cardiopulmonary bypass, 28.8 minutes (SEM \pm $0.58)$;

(5) cooling bypass to circulatory arrest $\left(18^{\circ} \mathrm{C}\right)$. 16.6 minutes (SEM \pm 1.72 ).

The mean duration of circulatory arrest was 61 minutes (SEM \pm 3.1$)$, while the mean duration of rewarming cardiopulmonary bypass was 38.2 minutes (SEM \pm 1.16 ). The mean interval between the termination of cardiopulmonary bypass and the end of the operation was 56.6 minutes (SEM \pm 7.19 ). None of the patients required any sympathomimetic agents at any time during the procedure. The data were analyzed using the Wilcoxon signed rank test for paired data, a $p$ value of less than 0.05 being accepted as statistically significant.

\section{Results}

All the patients survived the operation and none developed any arrhythmias during surface cooling. Figure 1 shows the progressive significant fall in heart rate that occurred with fall in temperature while Figure 2 shows the mean blood pressure that occurred during the procedure. The mean blood pressure fell as the temperature fell during surface cooling $(p<0.01)$, but there was a marked significant $-(p<0.05)$ rise in blood pressure immediately after the icebags were applied to the patient at the commencement of surface cooling compared with the mean blood pressure at induction. This rise in mean blood pressure was not associated with a concurrent rise in plasma catecholamine concentrations. Surface cooling with icebags to an oesophageal temperature of $28^{\circ} \mathrm{C}$ produced no significant change in either epinephrine or norcpinephrine plasma concentrations (Figure 3, Table II). However, following the sternal incision there was a significant rise in plasma epinephrine concentration from $93 \mathrm{pg} / \mathrm{ml}$ (SE \pm 51) to $1954 \mathrm{pg} / \mathrm{ml}$ (SE \pm 1308) $(p<0.05$ ). The plasma norepinephrine level did rise, but not significantly. However, there was no change in mean blood pressure or heart rate after the sternotomy incision.

There was also no change in plasma catecholamine levels during cardiopulmonary bypass with cooling. In addition, total circulatory 


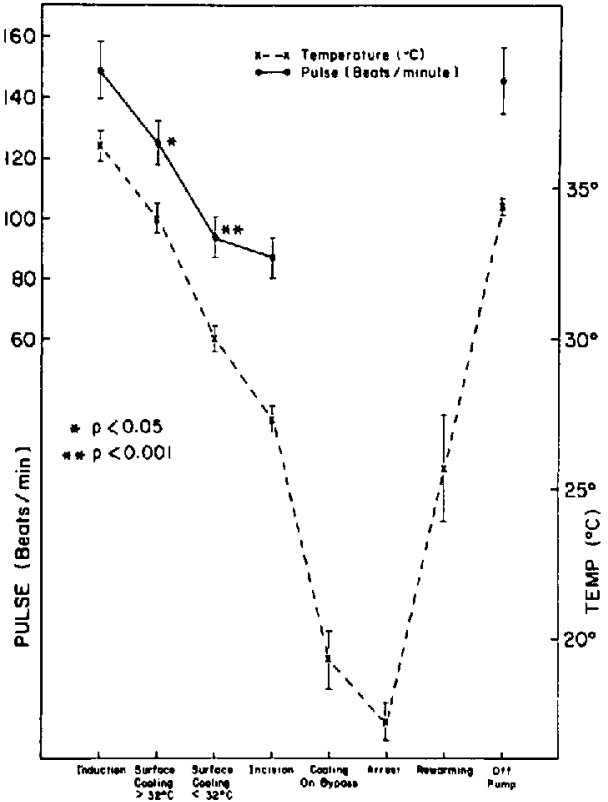

Figure I Mean heart rate during surface cooling. circulatory arrest and rewarming bypass. (Statistical comparisons refer to the immediately preceeding value.)

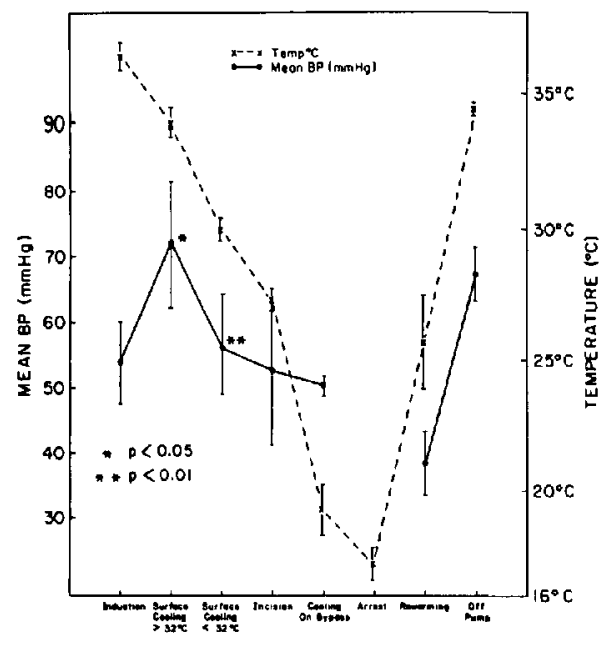

Figure 2 Mean blood pressure during surface cooling, circulatory arrest and rewarming bypass. (Statistical comparisons refer to the immediately preceeding value.)

arrest and drainage of the infants' blood volume to the reservoir chamber of the oxygenator was not associated with any change in plasma epinephrine or norepinephrine concentrations. How-

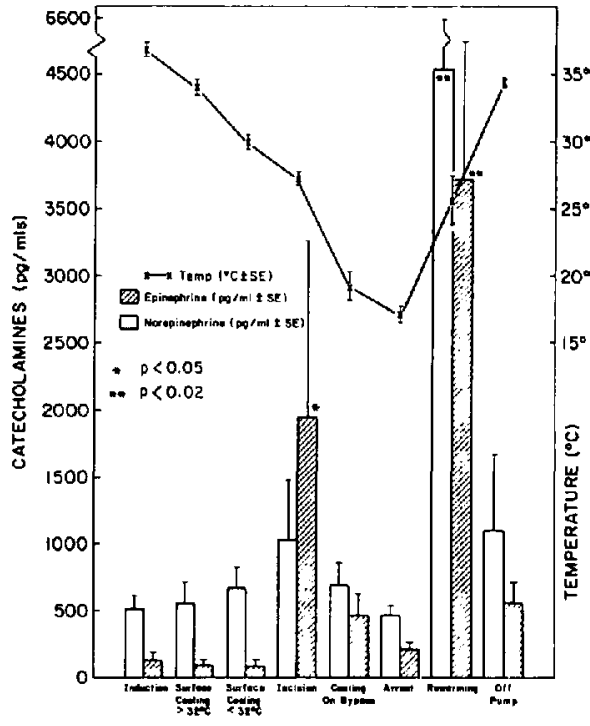

Figure 3 Mean plasma catecholamine concentrations during surface cooling, circulatory arrest and rewarming bypass. (Statistical comparisons refer to the immediately preceeding value.)

ever, the recommencement of cardiopulmonary bypass and rewarming perfusion after circulatory arrest caused a striking increase in plasma catecholamine levels. The mean plasma norepinephrine concentration rose from $466 \mathrm{pg} / \mathrm{ml}$ ( $\mathrm{SE} \pm 8 \mathrm{l}$ ) at circulatory arrest to $4543 \mathrm{pg} / \mathrm{ml}$ (SE \pm 2058 ) on rewarming bypass ( $\mathrm{p}$ $<0.02$ ), while the mean plasma epinephrine concentration rose from $218 \mathrm{pg} / \mathrm{ml}(\mathrm{SE} \pm 54$ ) at circulatory arrest to $3724 \mathrm{pg} / \mathrm{ml}(\mathrm{SE} \pm$ 1064) on rewarming bypass $(p<0.02)$. The plasma catecholamine concentrations fell once cardiopulmonary bypass was discontinued, when the infants temperature was $37^{\circ} \mathrm{C}$.

Table III shows the acid-base data obtained during the procedure. There was a mean base deficit of $-8.17 \mathrm{mmol} /$ litre $(S E \pm 1.67$ ) on rewarming bypass after the period of circulatory arrest.

\section{Discussion}

There are a number of clinical reports citing an increased incidence of arrthymias in infants undergoing surface cooling. ${ }^{2.18 .19}$ These arrhythmias range from sinus bradycardia and premature ventricular ectopic beats, to ventricular fibrillation and cardiac arrest. Indeed, some workers have abandoned surface cooling below $30^{\circ} \mathrm{C}$ because of the development of seri- 
TABLE II

Mean Plasma Catecholamine Concentrations During Profound Hypothermia, Circulatory arrest AND REWARNING BYPASS

\begin{tabular}{|c|c|c|c|c|c|c|c|c|}
\hline & Induction & $\begin{array}{l}\text { Surface } \\
\text { cooling } \\
\left(>32^{\circ} \mathrm{C}\right)\end{array}$ & $\begin{array}{c}\text { Surface } \\
\text { cooling } \\
\left(31-28^{\circ} \mathrm{C}\right)\end{array}$ & Sternotomy & $\begin{array}{l}\text { Cooling } \\
\text { w/Bypass }\end{array}$ & $\begin{array}{c}\text { Circulatory } \\
\text { arrest }\end{array}$ & Rewarming & $\begin{array}{c}\text { Off } \\
\text { pump }\end{array}$ \\
\hline $\begin{array}{l}\text { Norepinephrine } \\
(\mathrm{pg} / \mathrm{ml} \pm \mathrm{SEM})\end{array}$ & $\begin{array}{r}521 \\
\pm 90\end{array}$ & $\begin{array}{r}559 \\
+159\end{array}$ & $\begin{array}{r}666 \\
+167\end{array}$ & $\begin{array}{r}1035 \\
\pm 446\end{array}$ & $\begin{array}{r}690 \\
\pm 174\end{array}$ & $\begin{array}{r}466 \\
\pm 81\end{array}$ & $\begin{array}{r}4543 \dagger \\
+2058\end{array}$ & $\begin{array}{r}1107 \\
\pm 572\end{array}$ \\
\hline $\begin{array}{l}\text { Epinephrine } \\
(\mathrm{pg} / \mathrm{ml} \pm \mathrm{SEM})\end{array}$ & $\begin{array}{r}132 \\
\pm 59\end{array}$ & $\begin{array}{r}90 \\
\pm 46\end{array}$ & $\begin{array}{l}93 \\
\pm 51\end{array}$ & $\begin{array}{r}1954^{*} \\
\pm 1308\end{array}$ & $\begin{array}{r}470 \\
+164\end{array}$ & $\begin{array}{r}218 \\
\pm 54\end{array}$ & $\begin{aligned} & 3724+ \\
+ & 1064\end{aligned}$ & $\begin{array}{r}561 \\
\pm 152\end{array}$ \\
\hline
\end{tabular}

" $p<0.05$.

$f \mathrm{p}<0.02$.

Statistical comparisons refer to the immediately preceding value.

TABLE III

Acid-Base Data During Profound Hypothermia, Circulatory Arrest and Rewarming Bypass

\begin{tabular}{|c|c|c|c|c|}
\hline & $\begin{array}{l}\text { Surface } \\
\text { cooling }\end{array}$ & $\begin{array}{l}\text { Cooling } \\
\text { w/bypass }\end{array}$ & Rewarming & Off pump \\
\hline Mean $\mathrm{cH}^{+} \mathrm{nmol} / \mathrm{l} \pm \mathrm{SEM}$ & $23.99 \pm 1.61$ & $23.44 \pm 1.10$ & $39.81 \pm 3.84$ & $32.36 \pm 2.30$ \\
\hline Mean $\mathrm{pH} \pm \mathrm{SEM}$ & $7.62 \pm 0.03$ & $7.63 \pm 0.02$ & $7.40 \pm 0.02$ & $7.49 \pm 0.03$ \\
\hline Mean $\mathrm{Pa}_{\mathrm{Co}_{2} \pm \underset{(\mathrm{mm} \mathrm{Hg})}{\mathrm{SEM}(\mathrm{kPa})}}$ & $\begin{array}{l}2.19 \pm 0.26 \\
16.5 \pm 1.98\end{array}$ & $\begin{array}{l}2.46 \pm 0.12 \\
18.5 \pm 0.9\end{array}$ & $\begin{array}{l}3.70 \pm 0.31 \\
27.8 \pm 2.36\end{array}$ & $\begin{array}{l}3.63 \pm 0.39 \\
27.3 \pm 2.92\end{array}$ \\
\hline $\begin{array}{l}\text { Mean base deficit } \pm \text { SEM } \\
\quad(\mathrm{mmol} / \mathrm{l})\end{array}$ & $-2.5 \pm 1.96$ & $-2.0 \pm 1.21$ & $-8.17 \pm 1.67$ & $-2.5 \pm 0.85$ \\
\hline
\end{tabular}

All values have been corrected for temperature. ${ }^{16}$

ous arrhythmias. ${ }^{2}$ However, we did not encounter any arrhythmias in the infants that we studied, although heart rate fell with temperature.

Our study clearly shows that plasma catecholamine concentrations did not rise during surface cooling of the infants to $28^{\circ} \mathrm{C}$ or core cooling to $18^{\circ} \mathrm{C}$. We therefore conclude that the elevation of catecholamines previously reported in animals does not occur in infants cooled using the anaesthetic techniques that we have described. It would, therefore, appear unlikely that the ventricular irritability recognized below $30^{\circ} \mathrm{C}$ in anaesthetized infants is due to catecholamine excess. The aetiology of cardiac arrhythmias during surface cooling, therefore, remains controversial. Other causes which have been suggested include alterations in the acid base state, electrolyte imbalance including hypokalaemia and the effect of cold causing local conduction defects within the myocardium itself. ${ }^{20.21 .22}$

The effect of anaesthetic agents on catecholamine release should also be considered. Our patients were anaesthetized with halothane. Although plasma catecholamine concentrations are depressed in rats anaesthetized by halo- thane, ${ }^{23}$ similar studies in man show an increase in plasma norepinephrine concentrations during the induction of halothane anaesthesia at normal temperatures. ${ }^{24}$ This may have been a mechanism compensatory to the fall in blood pressure that occurs with halothane anaesthesia, as there was an inverse relationship between the ratepressure product and plasma norepinephrine concentrations. Roizen and his co-workers have also shown that general anaesthetics reduce stress-induced increases in levels of plasma total catecholamines and norepinephrine in rats. ${ }^{2 s}$ It is interesting that in our study there was an increase in plasma catecholamines after the "stress" of the sternotomy incision which was not associated with a change in mean blood pressure or heart rate, possibly representing an altered receptor sensitivity at lower temperatures. The anaesthetic technique that we used before the commencement of cardiopulmonary bypass may have blocked sympathoadrenal catecholamine release and thus prevented ventricular imitability.

A variety of physiological stimuli can give rise to catecholamine secretion including hypotension, hypovolaemia, anoxia and asphyxia. ${ }^{26,27}$ 
The sympathoadrenal response to hypovolaemia and haemorrhage is well established, the vascular effects of the increase in catecholamines causing a redistribution of the contracted blood volume to maintain vital cerebral and coronary blood flow. It is, therefore, surprising that circulatory arrest and drainage of the infant's entire blood volume to the reservoir of the pump oxygenator was not associated with any change in plasma epinephrine or norepinephrine in the infants studied. This contrasis with previous experience in adults at normal temperatures where haemorrhage is a potent baroreceptor stimulus that results in a greatly increased output of plasma catecholamines ${ }^{27.28}$ and must reflect an alteration in the response to hypovolaemia in infants at low temperatures. It is interesting that other experiments have demonstrated that the baroreceptor reflex is either greatly reduced or abolished at $20-22^{\circ} \mathrm{C}$, as assessed by the reduction in preganglionic cervical sympathetic activity evoked by electrical stimulation of the aortic depressor nerve. ${ }^{29}$

Rewarming perfusion after the period of circulatory arrest caused a striking increase in plasma epinephrine and norepinephrine concentrations. The mechanism is unclear. However, catecholamines secreted during the period of circulatory arrest may accumulate in the tissues and enter the circulation on rewarming perfusion. Hypothermia may affect the neuronal reuptake of catecholamines or inhibit their metabolic breakdown. Another possibility is that the washout from ischaemic tissues of metabolic products produced during circulatory arrest may act as a stimulus to catecholamine release. An excellent correlation has been shown between cord norepinephrine levels at birth and acidosis ${ }^{30}$ suggesting that metabolic acidosis may stimulate a catccholamine response in young infants.

During this study the mean base deficit rose to $-8.17 \mathrm{mmol} / \mathrm{l}(\mathrm{SE} \pm 1.67)$ on rewarming bypass which confirms the observations of others of the acidosis which develops during circulatory arrest and the rise in serum lactate which has been reported during rewarming bypass. ${ }^{12,13}$ The accumulation of catecholamines and metabolic products in the infants during circulatory arrest with their subsequent release into the circulation during rewarming may account, at least in part, for the striking elevation of catecholamine levels shown in this study.

We conclude, therefore, that induced hypothermia and exsanguination in infants using the techniques described here is not associated with elevation of catecholamines, but that rewarming cardiopulmonary bypass following circulatory arrest and exsanguination is associated with a striking elevation of catecholamines, which may be related to the washout either of products of metabolism or of catecholamines produced during the period of arrest

\section{REFERENCES}

1. JohnSON. D.G., HaYward, J.S., Jacobs. T.P.. COLLIS, M.L., ECKERSON, J.D. \& WILLIAMS, R.H. Plasma norepinephrine responses of man in cold water. J. Appl. Physiol. 43: 216-220 (1977)

2. Warner, W.A., ANTON. A.H., Anderson, T.W. \& SWOFFord, L.J. Ventricular fibrillation and catecholamine responses during profound hypothermia in dogs. Anesthesiology 33: 43-51 (1970).

3. Bennett, C.R., Smookler. H.H. \& BuckleY, J.P. Prevention of ventricular fibrillation during induced hypothermia by N,N-diisopropyl-N'-isoamyl-N'-diethylaminoethylurea $\left(P_{286}\right)$. J. Pharmocol. Exp. Ther. 159: 115-122 (1968).

4. ColE, A.F.D. \& Jacobs, J.A. Propranolol in the management of cardiac arrhythmias during hypothermia. Canad. Anaes. Soc. J. 14: 44-48 (1967).

5. FINLAY, W.E.I, \& DYkes. W.S. Cardiac arrhythmias during hypothermia controlled by propranolol. Anaesthesia 23: 631-635 (1968).

6. Stanton, H.C. \& Meull.fer, R.L. Metabolic responses to cold and catecholamines as a function of age in swine (sus domesticus). Comp. Biochem. Physiol. 45A: 215-225 (1973).

7. LeDuc, J. Effect of exposure to cold on the production and release of catecholamines. $I n$ : Catecholamine Production and Release in Exposure and Acclimation to Cold. Acta. Physiol, Scand. 53. Suppl. 183, Ch. III, 18-38(1961).

8. Leblanc, J., Vallieke, C.R. \& Oakson, G. The sympathetic nervous system in short term adaptation to cold. Canad. J. Physiol. Pharmacol. 49: 96-10l (1971).

9. Hirvonen, J. Necropsy findings in fatal hypothermia cases. Forensic Science 8: 155-164(1976).

10. Hine, I.P., Wood, W.G., Mainwaring-Burton, R.W., Butler, M.J., IRving, M.H. \& BoOKer, B. The adrenergic response to surgery involving cardiopulmonary bypass, as measured by plasma and urinary catecholamine concentrations. $\mathrm{Br}$. J. Anaesth. 48: 355-362 (1976).

11. Balasaraswathi. K., Glisson. S.N., El-Etr, A.A. \& PIFARRE, R. Serum epinephrine and norepinephrine during valve replacement and aorta-coronary bypass. Canad. Anaesth. Soc. J. 25: 198-203 (1978).

12. Johnston, A.E., Radde, I.C., Steward. D.J. \& TAYLOR, J. Acid-base and electrolyte changes in infants undergoing profound hypothermia for surgical correction of congenital heart defects. Can. Anaesth. Soc. J. 2l: 23-45 (1974).

13. Seelye, E.R., Harris, E.A., Souire, A.W. \& BarRatT-Boyes, B.G. Metabolic effects of deep hypothermia and circulatory arrest in infants during cardiac surgery. Br. J. Anaesth. 43; 449-459 (1971). 
14. Passon, P.G. \& Peuler, J.D. A simplified radiometric assay for plasma norepinephrine and epinephrine. Analytical Biochemistry 51: 618-631 (1973).

15. Kelman, G.R. \& NuNN, J.F. Nomograms for correction of blood $\mathrm{P}_{\mathrm{O}_{2}}, \mathrm{P}_{\mathrm{CO}_{2}}, \mathrm{pH}$ and base excess for time and temperature. J. Appl. Physiol. 21: 1484-1489(1966)

I6. RAtTenborg, C.C., blood gas evaluator, Medical Evaluator, PS Services, 4646 N. Clifton Avenue, Chicago. Illinois 60640 .

17. Severinghaus, J.W., Stupfel, M. \& Bradley, A.F. Variations of carbonic acid $\mathrm{pK}$ with $\mathrm{pH}$ and temperature. J. Appl. Physiol. 9: 197-200 (1957).

18. Bigelow. W.G. Mustard, W.T. \& EVANS, J.G Some physiologic concepts of hypothermia and their applications to cardiac surgery. J. Thorac. Surg. 28: 463-477 (1954).

19. Caldwell. T.B., Blunk, J.N. \& Escubak, A. Experience with deep hypothermia and elective circulatory arrest for cardiac surgery in infants. Southern Med. J. 70: 681-685 (1977).

20. Mouritzen, C.V. \& Anderson, M.N. Myocardial temperature gradients and ventricular fibrillation during hypothermia. J. Thorac. Cardiovasc. Surg. 49: 937-944(1965)

21. BRoOM, B. \& SELLICK, B.A. Controlled hypercapnia in open heart surgery under hypothermia. Lancet $2: 452-455$ (1965).

22. Covino, B.G. \& D'Amato. H.E. Mechanism of ventricular fibrillation in hypothermia. Circ. Res. 10: 148-155 (1962)

23. ROIZEN. M.F., MOSS, J. HENRY, D.P. \& KOPIN, I.J. Effect of halothane on plasma catecholamines. Anesthesiology 4I: 432-439 (1974).

24. ROIZEN, M.F. Forbes, A.F. Gerson, J.J. Grobecker, H. \& Eger. E.l. Plasma norepin- ephrine increases with induction of halothane anesthesia. Annual Meeting of the American Society of Anesthesiologists. Abstracts of Scientific Papers. p. 15 (1978)

25. Rolzen. M.F. Moss. J.. Henry, D.P., Weise. V. \& KoPIN. I.J. Effect of general anesthetics on handling and decapitation-induced increases in sympathoadrenal discharge. J. Pharmac. and Exp. Ther. 204: 11-18 (1978)

26. LEwis, G.P. Physiological mechanisms controlling secretary activity of adrenal medulla. In: Handbook of Physiology. Sec. 7. Vol. VI (ed.) Blaschko. H. Sayers, G. and Smith. A.D., pp. 309-319, Washington, D.C., American Physiological Society (1975)

27. Oyama, T. Matsuki, A. Kudo, T. Kudo, M. Yamashita, M. \& Ishailara. H. Effect of corticosteroids on endocrine function in haemorrhagic shock. Canad. Anacsth. Soc. J. 25: 7-17 (1978).

28. Benedict, C.R., \& Grahame-Smith, D.G. Plasma noradrenaline and adrenaline concentrations and dopamine-beta-hydroxylase activity in patients with shock due to septicaemia. trauma and haemorrhage. Quarterly Journal of Medicine. New Series XLVII, 1-20(1978)

29. Kaul, S.V., Beard, D.J. \& Millar, R.A. Preganglionic sympathetic activity and baroreceptor responses during hypothermia. $\mathrm{Br}$. J. A naesth. 45: 433-439(1973).

30. Wright, R.G., Schnider, S.M., Gershon. L., Rolbin, S.H., Rolzen, M. JohnSon, J. \& Jones. $M$. Maternal and fetal norepinephrine levels during epidural anesthesia for elective cesarean section. Annual Meeting of the American Society of Anesthesiologists. Abstracts of Scientific Papers, p. 109. 1978

\section{RÉSUMÉ}

Il a été suggéré que l'incidence augmentée d'arythmies ventriculaires observées sous $30^{\circ} \mathrm{C}$ peut être liée à une élévation des catécholamines. Des concentrations élevées de catécholamines ont été rapportées chez l'animal rendu hypothermique.

Les auteurs ont mesuré les concentrations plasmatiques d'épinéphrinc et de norépinéphrine durant l'hypothermic profonde avec arrêt circulatoire chez l'enfant de moins d'un an, au cours de correction de cardiopathie congénitale. On n'a pas relevé de modifications significatives du taux d'épinéphrine et de norépinéphrine au cours du refroidissement (hypothermie de surface) jusqu'à $28^{\circ} \mathrm{C}$. La sternotomie n'était effectuée qu'au moment où cette température était atteinte. A près mise en route de la CEC avec refroidissement jusqu’à $18^{\circ} \mathrm{C}$. on procédait à la réparátion de la lésions sous arrêt circulatoire en exsanguination. On n'a pas observé d'élévation des catécholamines au cours de l'arrêt circulatorie et de l'exsanguination. Cependant, I'on a observé des élévations marquées de l'épinéphrine et de la norépinéphrine à la reprise de la CEC et du réchauffement. La concentration plasmatique moyenne de norépinéphrine s'élevait alors du taux de $466 \mathrm{pg} / \mathrm{ml}$ ( \pm 81 ) observé au cours de l'arrét circulatoire jusqu'à une valeur de $4353 \mathrm{pg} / \mathrm{ml}( \pm 2058)$ au réchauffement. Le taux moyen d'épinéphrine plasmatique passait de $218 \mathrm{pg} / \mathrm{ml}( \pm 54)$ au cours de l'arrèt circulatoire à $3724 \mathrm{pg} / \mathrm{ml}( \pm 1064)$. Les taux de ces catécholamines retombaient après cessation de la CEC alors que la température des enfants était de $37^{\circ} \mathrm{C}$.

Il semblerait donc improbable que l'irritabilité myocardique observée sous hypothermie lorsque la température tombe sous $30^{\circ} \mathrm{C}$, soit due à un excès de catécholamines. L'accumulation de catécholamines et/ou de produits métaboliques au cours de l'arrêt circulatoire chez l'enfant el leur arrivée dans la circulation au cours du réchauffement, pourraient expliquer les taux éleyés observés durant cette période. 